\title{
Level and determinants of willingness to donate organs among the general public: A cross-sectional survey in China
}

\author{
Xiaojing Fan \\ Sirui Zheng \\ Liverpool School of Tropical Medicine \\ Meng Li \\ Xi'an Jiaotong University \\ Duolao Wang \\ Liverpool School of Tropical Medicine \\ Enchang Li ( $\nabla$ wenhai188@163.com ) \\ https://orcid.org/0000-0002-0436-8289 \\ Zhongliang Zhou \\ Xi'an Jiaotong University \\ Weirong Zheng \\ Wenzhou Medical University \\ Lingling Wang \\ Wenzhou Medical University \\ Qing Zhang \\ Wenzhou Medical University \\ Yingying Li \\ Wenzhou Medical University \\ Jianfeng Lin \\ Wenzhou Medical University
}

Xi'an Jiaotong University https://orcid.org/0000-0002-6704-0678

\section{Research article}

Keywords: General public, willingness, organ donation, determinants, China

Posted Date: November 9th, 2020

DOI: https://doi.org/10.21203/rs.3.rs-26580/v2

License: (c) (i) This work is licensed under a Creative Commons Attribution 4.0 International License. Read Full License

Version of Record: A version of this preprint was published at Developing World Bioethics on January 15th, 2022. See the published version at https://doi.org/10.1111/dewb.12339. 


\section{Abstract}

Background: This study aims to assess the level and determinants of the general public's willingness to organ donation.

Methods: We conducted a population-based cross-sectional study of 4261 participants in China. The primary outcome was the willingness to donate organs. Logistic regression modelling was used to determine the factors that affect willingness to donate organs.

Results: Overall, the proportion of participants who showed a willingness to donate organs was $47.45 \%(95 \% \mathrm{Cl}: 0.46,0.49)$ in this study. Logistic regression modelling showed participants from Western $(\mathrm{OR}=1.33,95 \% \mathrm{Cl}=1.11-1.59)$ and Eastern $\mathrm{China}(\mathrm{OR}=1.40,95 \% \mathrm{Cl}=1.19-1.65)$ were $\mathrm{more}$ willing to donate organs compared with those from Central China. The odds of being willing to donate organs was higher in females than males $(\mathrm{OR}=1.35,95 \% \mathrm{Cl}=1.17-1.55)$; and was higher in those participants with experience of organ donation $(\mathrm{OR}=1.58,95 \% \mathrm{Cl}=1.13-2.21)$, experience of caring for organ transplant patients $(\mathrm{OR}=1.45,95 \% \mathrm{Cl}=1.01-2.07)$, and those undertaking related voluntary activities $(\mathrm{OR}=1.67,95 \% \mathrm{Cl}=1.45-1.94)$, than those without.

Conclusion: The general public's level of willingness to organ donation was not high in China. Geographical region, gender, experience of organ donation related activities, taking care of organ transplant patients and volunteering in related activities were independently associated with participants' willingness to donate organs.

\section{Background}

Since the 1950s, organ transplantation has been considered the most effective life-saving therapeutic option to treat patients who suffer from endstage organ failure ${ }^{1-2}$. Globally, there is a severe imbalance between supply and demand, the need for organs dramatically exceeds the number of donated organs available for transplantation ${ }^{3}$. Countries around the world attempt to increase the number of organs donors to meet the demand. Rate of organ donation per million population ( $\mathrm{pmp}$ ) is higher in Western countries. In the United States, registration rates for organ donation range from $20 \%$ to $60 \%{ }^{4}$, and in 2019 , Spain was the world leader in organ donation, with 48.9 pmp deceased organ donors ${ }^{5}$. In Europe, Greece has the fewest organ donations; with 5.5 of donors pmp ${ }^{5,6}$. Previous studies have shown that organ donation rates in Asia tend to be lower than in Western countries $^{7-9}$. In 2019, the organ donation rate in Iran was 11.26 pmp, 0.75 pmp in Japan, and 4.43 pmp in China ${ }^{5}$. Thus, increasing the rate of organ donation in Asian populations represents a significant public health challenge.

In China, The Organ Transplantation Program began in the 1960s, and has been successful in saving the lives of thousands of patients with advanced organ diseases. Although 10,000 transplantations are performed in China each year, the supply of organs is inadequate to meet the increasing demand ${ }^{9}$, and the majority of patients with vital or non-vital organ failure are deprived of a new and better quality of life ${ }^{10}$. To encourage organ donation, special measures have been taken since the 1960s. For example, a body-donor monument was built to commemorate the contributors in Wuhan $2005^{11}$. Furthermore, in 2007, regulation of human organ transplantation was implemented by the authorities and the Human Organ Donation plan was launched post- $2013^{12}$.

From the perspective of engaging the general public and improving the rate of organ donation it is essential to understand the characteristics of organ donors. Previous studies have shown that a potential organ donor was characterized as being highly educated, well informed and enthusiastic about donation and would have had a discussion with family members regarding this issue ${ }^{13-14}$.

Some studies have provided insight into the status and determinants of organ donation ${ }^{14-17}$. However, these studies have certain limitations: For example, in one study only 1074 effective questionnaires were returned by the participants, indicating a small sample size ${ }^{15}$. Further, other studies comprised of specific populations only, such as, medical students and health professionals, ${ }^{16,17}$. In addition, individuals who had undergone renal transplantation showed a positive attitude towards deceased donation than their caregivers in Hunan ${ }^{14}$. Another limitation of these studies was the geographic areas chosen to conduct the studies were specific regions and cities of China, and not representative of the country as a whole.

This study aims to explore the level and determinants of willingness towards organ donation by using a large national sample obtained from Eastern, Central and Western China. The results will provide important information for scientists and policymakers to implement targeted measures to improve the organ donation rate in China.

\section{Methods}

\section{Data Source}

Due to the cost-effectiveness, a multistage stratified sampling method was applied to sample the research sites. The sampling method was divided into four stages, comprised of different sampling units. For the first stage we selected a province from each of three regions of China: Zhejiang province in the East, Henan province in the Centre and Shaanxi province in the West. Next, we selected the capital city of each province: Hangzhou, Zhengzhou and Xi'an, respectively. Subsequently, the principal investigator in each city selected 6 communities based on convenience sampling method. The procedure can be described as follows. Firstly, investigators conducted an intercept survey on the streets, parks, shops and other public 
places in a selected community based on the principle of convenience, facilitated by a local village doctor or public health specialist from the community. Secondly, the local village doctor or public health specialist introduced the survey team, explained the purpose of this survey and the length of time spent on questionnaire to the intercepted people, and invited them to participate the survey. And finally, the survey team conducted a face-to-face interview of the intercepted people who agreed and signed the informed consent form.

According to the results of a previous study, the rate of willingness towards organ donation was $49 \%{ }^{17}$. Therefore, the sample size was calculated as 1334 for each site with a permissible error of $\delta=3 \%$, a type I error of $a=0.05$ and an expected $20 \%$ nonresponse rate.

The inclusion criteria of participants were: (1) people who were more than 16 years old and cognitively or physically able to answer questions in a 1 hour interview; (2) people who could clearly communicate orally; (3) people who were without mental illnesses. In this study, 5200 people received a personal invitation to participate, and $17.2 \%$ of them rejected to participate. A total of 4305 participants were included and there were 1409,1408 and 1488 participants from Western, Central and Eastern China respectively from October to December 2019. During the survey, a structured questionnaire that included questions relating to willingness to donate organs was administered individually to each participant (Additional file 1). Forty-four participants failed to answer questions relating to willingness to donate and have been excluded from the analysis. We undertook a statistical analysis of the remaining 4261 participant questionnaires.

\section{Study variables}

The primary outcome of this study was the response of willingness to donate organs, recorded as a binary variable of no (0) or yes ( 1 ) in the questionnaires. The proportion of those willing to donate organs was calculated by the number of participants who were willing to organ donation over the total number of participants who responded ${ }^{18}$. Determinants in this study were selected based on previous studies but constrained by the variables collected in the survey ${ }^{19-21}$. They included residence type (urban or rural), geographical location (region), demographic characteristics (gender, age, marital status, education, employment and monthly income) and personal experiences (experience of organ donation, taking care of organ transplant patients, and voluntary related activities).

\section{Quality control}

To ensure the high return rate of valid questionnaires and reduce investigator bias, we invited experts from the Wenzhou Medical University, Liverpool School of Tropical Medicine, Hangzhou Normal University, Xi'an Jiaotong University and Zhengzhou University to train the investigators in terms of interviewing skill and operational procedures. Data such as demographics, experiences and willingness to organ donation were collected using structured questionnaires (Additional file 1). The interview process was standardized prior to formal investigation. The entire investigation was conducted under the supervision of senior researchers.

\section{Statistical analyses}

A database was established using EpiData 3.1 software (developed by EpiData Association, Odense. Denmark) and data was double entered to ensure data quality. Categorical variables were summarised using number and percentages. Distributions of basic characteristics by residence, and attitude towards organ donation were compared using Chi-square tests. Logistic regression modelling was applied to identify the determinants of participants' willingness to organ donation, controlling for other confounding factors. Odds ratios (ORs) with $95 \%$ confidence intervals (Cls) were derived from logistic regression modelling. The statistical results and figures were processed with STATA statistical software version 12.0 (StataCorp LP, College station 77845, USA) software and Excel 2016, respectively. A two-tailed $p$ value $<0.05$ was considered statistically significant.

\section{Results}

\section{Basic Characteristics}

The descriptive statistics of the participants are shown in Table 1. Of the 4261 respondents, 2008 (47.13\%) and 2253 (52.87\%) lived in urban and rural areas, respectively. Among these participants, 1382 came from the West, 1393 from the Central and 1486 from the East. The respondents were more female than male and had a median age $\leq 30$ years old. The overall results showed significant differences in characteristics between urban and rural participants with the $p$-value $<0.05$.

Table 1 Basic characteristics of participants $(n=4261)$ 


\begin{tabular}{|c|c|c|c|c|c|}
\hline \multirow[t]{2}{*}{ Characteristics } & \multicolumn{2}{|l|}{ Residence [n (\%)] } & \multirow[t]{2}{*}{$N$} & \multirow[t]{2}{*}{$\chi^{2}$} & \multirow[t]{2}{*}{$P$} \\
\hline & Urban $(n=2008)$ & Rural (n=2253) & & & \\
\hline \multicolumn{6}{|l|}{ Geographical } \\
\hline Region & & & & 103.76 & $<0.001$ \\
\hline Central & $753(37.50)$ & $640(28.41)$ & 1393 & & \\
\hline West & 498(24.80) & 884(39.24) & 1382 & & \\
\hline East & $757(37.70)$ & $729(32.36)$ & 1486 & & \\
\hline \multicolumn{6}{|l|}{ Demographic } \\
\hline Gender & & & & 5.77 & 0.016 \\
\hline Male & $905(45.25)$ & 935(41.59) & 1840 & & \\
\hline Female & 1095(54.75) & $1313(58.41)$ & 2408 & & \\
\hline Age (years) & & & & 60.72 & $<0.001$ \\
\hline$\leq 30$ & 1024(51.98) & $1203(54.53)$ & 2227 & & \\
\hline $31-40$ & $554(28.12)$ & 488(22.12) & 1042 & & \\
\hline $41-50$ & $242(12.28)$ & 218(9.88) & 460 & & \\
\hline $51-60$ & $96(4.87)$ & $224(10.15)$ & 320 & & \\
\hline$\geq 61$ & $54(2.75)$ & $73(3.32)$ & 127 & & \\
\hline Marital status & & & & 7.18 & 0.007 \\
\hline Others $^{1}$ & $1001(49.98)$ & $1031(45.86)$ & 2032 & & \\
\hline Married & $1002(50.02)$ & $1217(54.14)$ & 2219 & & \\
\hline Education & & & & 162.91 & $<0.001$ \\
\hline$\leq$ Primary school & $63(3.14)$ & 166(7.38) & 229 & & \\
\hline Middle-High school & $596(29.70)$ & $998(44.38)$ & 1594 & & \\
\hline$\geq$ University & $1348(67.16)$ & $1085(48.24)$ & 2433 & & \\
\hline Employment & & & & 33.64 & $<0.001$ \\
\hline No & $1107(55.21)$ & $1440(63.94)$ & 2547 & & \\
\hline Yes & $898(44.79)$ & $812(36.06)$ & 1710 & & \\
\hline \multicolumn{3}{|c|}{ Monthly income (Chinese yuan) } & & 88.00 & $<0.001$ \\
\hline$<3300$ & $847(42.72)$ & $1230(55.21)$ & 2077 & & \\
\hline $3300-5999$ & $570(28.74)$ & $601(26.97)$ & 1171 & & \\
\hline $6000-9999$ & $370(18.66)$ & $271(12.16)$ & 641 & & \\
\hline$>10000$ & $196(9.88)$ & $126(5.66)$ & 322 & & \\
\hline \multicolumn{6}{|l|}{ Personal experience } \\
\hline \multicolumn{6}{|c|}{ Do you or relatives or friends have any experience of organ donation? } \\
\hline No & $1717(94.13)$ & $1860(95.98)$ & 3577 & 6.81 & 0.009 \\
\hline Yes & $107(5.87)$ & $78(4.02)$ & 185 & & \\
\hline \multicolumn{4}{|c|}{ Have you taken care of organ transplant patients? } & 6.15 & 0.013 \\
\hline No & $1898(94.95)$ & $2168(96.48)$ & 4066 & & \\
\hline Yes & $101(5.05)$ & $79(3.52)$ & 180 & & \\
\hline \multicolumn{3}{|c|}{ Have you participated in volunteer activities? } & & 21.12 & $<0.001$ \\
\hline No & $1161(58.11)$ & $1460(64.98)$ & 2621 & & \\
\hline
\end{tabular}



Yes
837(41.89)
787(35.02)
1624

${ }^{1}$ Others include unmarried, divorce, widowed and living with a partner.

\section{Proportion of willingness to donate organs}

Overall, $47.45 \%$ (95\%Cl: $0.46,0.49)$ of participants were willing to donate organs in this study. A total of (978/2008) 48.71\% urban and (1045/2253) $46.38 \%$ rural participants indicated a positive attitude towards organ donation $\left(\chi^{2}=2.30, P=0.130\right)$. The results of the empirical results from the urban and rural areas are presented in Table 2 and 3 . There were significant differences in the proportions of willingness to donate organs among demographic characteristics and personal experiences (Table 2). Individuals or relatives and friends of individuals who had experienced organ donation, and individuals taking care of organ transplant patients or undertaking voluntary related activities were more likely to donate an organ (Table 2). Amongst rural respondents, there was no significant difference in the proportion participants' willingness to donate organs, according to their monthly income $P>0.05$ (Table 3).

Table 2 Proportion of participants from urban areas willing to donate organs according to geographic and demographic characteristics $(n=2008)$ 


\begin{tabular}{|c|c|c|c|c|}
\hline \multirow[t]{2}{*}{ Characteristics } & \multicolumn{2}{|c|}{ Willing to donate organs [n (\%)] } & \multirow{2}{*}{$x^{2}$} & \multirow[t]{2}{*}{$P$} \\
\hline & No & Yes & & \\
\hline \multicolumn{5}{|l|}{ Geographical } \\
\hline Region & & & 39.06 & $<0.001$ \\
\hline Central & 449(59.63) & $304(40.37)$ & & \\
\hline West & $251(50.40)$ & $247(49.60)$ & & \\
\hline East & $330(43.59)$ & $427(56.41)$ & & \\
\hline \multicolumn{5}{|l|}{ Demographic } \\
\hline Gender & & & 23.33 & $<0.001$ \\
\hline Male & $518(57.24)$ & $387(42.76)$ & & \\
\hline Female & 508(46.39) & $587(53.61)$ & & \\
\hline Age (years) & & & 36.41 & $<0.001$ \\
\hline$\leq 30$ & $460(44.92)$ & $564(55.08)$ & & \\
\hline $31-40$ & $319(57.58)$ & $235(42.42)$ & & \\
\hline $41-50$ & 135(55.79) & $107(44.21)$ & & \\
\hline $51-60$ & $64(66.67)$ & $32(33.33)$ & & \\
\hline$\geq 61$ & $27(50.00)$ & $27(50.00)$ & & \\
\hline Marital status & & & 27.12 & $<0.001$ \\
\hline Others & $456(45.55)$ & $545(54.45)$ & & \\
\hline Married & $573(57.19)$ & $429(42.81)$ & & \\
\hline Education & & & 13.07 & 0.001 \\
\hline$\leq$ Primary school & $40(63.49)$ & $23(36.51)$ & & \\
\hline Middle-High school & $334(56.04)$ & $262(43.96)$ & & \\
\hline$\geq$ University & 655(48.59) & 693(51.41) & & \\
\hline Employment & & & 17.93 & $<0.001$ \\
\hline No & $521(47.06)$ & $586(52.94)$ & & \\
\hline Yes & $508(56.57)$ & $390(43.43)$ & & \\
\hline \multicolumn{3}{|c|}{ Monthly income (Chinese yuan) } & 30.40 & $<0.001$ \\
\hline$<3300$ & $376(44.39)$ & $471(55.61)$ & & \\
\hline $3300-5999$ & $327(57.37)$ & $243(42.63)$ & & \\
\hline $6000-9999$ & 213(57.57) & $157(42.43)$ & & \\
\hline$>10000$ & $100(51.02)$ & $96(48.98)$ & & \\
\hline \multicolumn{5}{|l|}{ Personal experience } \\
\hline \multicolumn{5}{|c|}{ Do you or any relatives or friends have any experience of organ donation? } \\
\hline No & $853(49.68)$ & $864(50.32)$ & 5.20 & 0.023 \\
\hline Yes & $41(38.32)$ & $66(61.68)$ & & \\
\hline \multicolumn{3}{|c|}{ Have you taken care of organ transplant patients? } & 10.40 & 0.001 \\
\hline No & $989(52.11)$ & $909(47.89)$ & & \\
\hline Yes & $36(35.64)$ & $65(64.36)$ & & \\
\hline \multicolumn{3}{|c|}{ Have you participated in some volunteer activities? } & 85.57 & $<0.001$ \\
\hline No & $697(60.03)$ & 464(39.97) & & \\
\hline Yes & $327(39.07)$ & $510(60.93)$ & & \\
\hline \multicolumn{5}{|c|}{ Page 6/14 } \\
\hline
\end{tabular}


Table 3 Proportion of participants from rural areas willing to donate organs according to geographic and demographic ( $\mathrm{n}=2253$ ) 


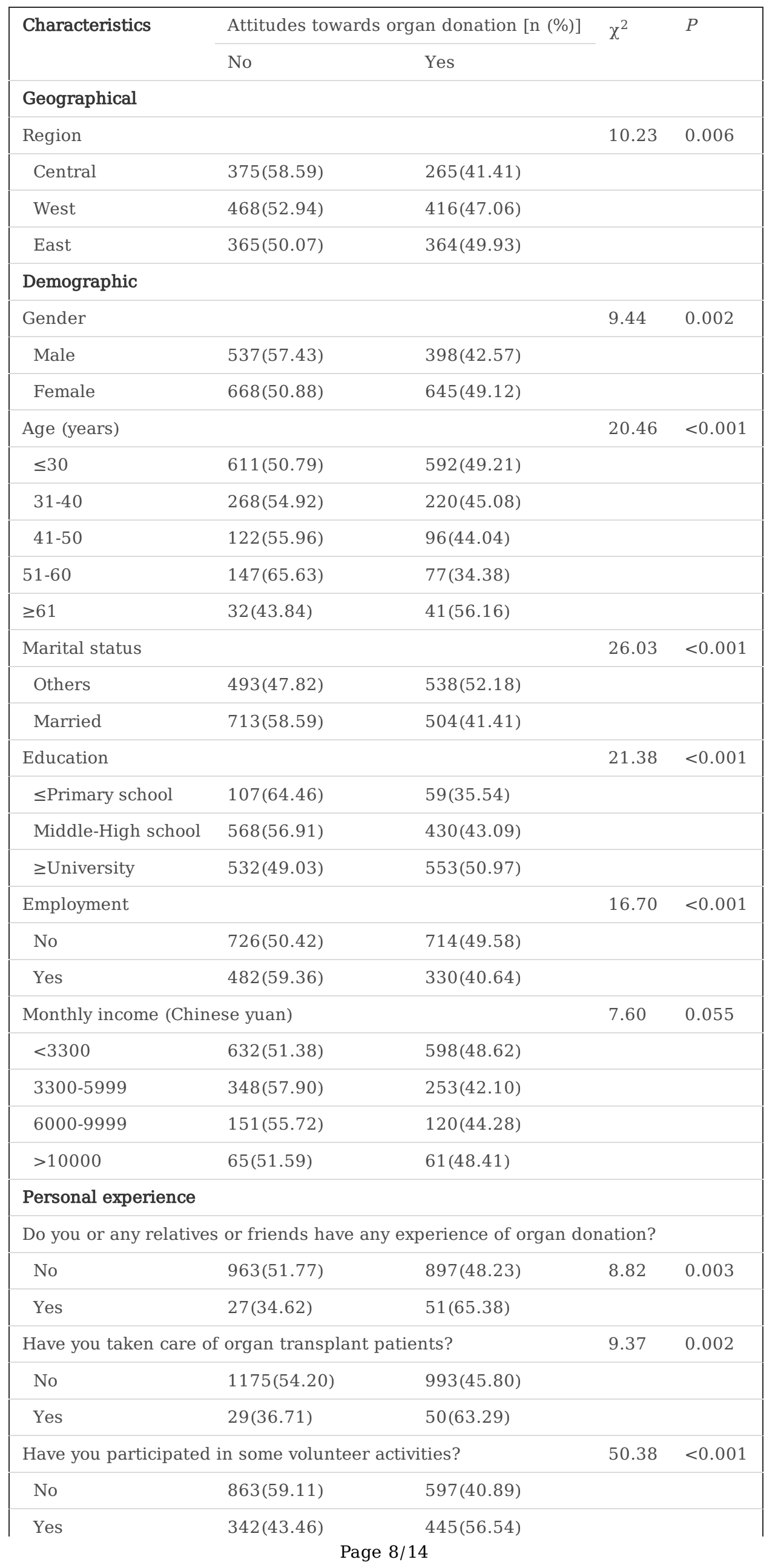


Determinants of willingness to donate organs

Overall, the results of the logistic regression model in Table 4 show there were no significant difference in the odds of willingness to donate organs between urban and rural participants when adjusting geographical, demographic and personal experience characteristics $(\mathrm{OR}=0.94,95 \% \mathrm{Cl}=0.82-1.06$, $P=0.421)$. The odds of being willing to donate an organ were 1.33 times higher for participants in Western $\mathrm{China}(95 \% \mathrm{Cl}=1.11-1.59, P=0.002)$ and 1.40 higher in Eastern China $(95 \% \mathrm{Cl}=1.19-1.65, P<0.001)$ than those in Central China. The odds of willingness to organ donation in female participants was higher than in male participants $(\mathrm{OR}=1.35,95 \% \mathrm{Cl}=1.17-1.55, P<0.001)$. Participants who had experience of organ donation $(\mathrm{OR}=1.58,95 \% \mathrm{Cl}=1.13-$ $2.21, P=0.008)$, who took care of organ transplant patients $(\mathrm{OR}=1.45,95 \% \mathrm{Cl}=1.01-2.07, P=0.043)$ or who were involved in voluntary related activities $(\mathrm{OR}=1.67,95 \% \mathrm{Cl}=1.45-1.94, P<0.001)$ were more likely to donate an organ $(P<0.05)$.

Table 4 Multivariate analysis of the determinants of willingness to organ donation by logistic regression model 


\begin{tabular}{|c|c|c|c|c|c|c|c|c|c|c|c|c|}
\hline \multirow[t]{3}{*}{ Characteristics } & \multicolumn{4}{|c|}{ All (n=4261) } & \multicolumn{4}{|c|}{ Urban $(n=2008)$} & \multicolumn{4}{|c|}{ Rural (n=2253) } \\
\hline & \multirow{2}{*}{$\mathrm{OR}^{1}$} & \multicolumn{2}{|c|}{$95 \% \mathrm{CI}^{2}$} & \multirow[t]{2}{*}{$P$} & \multirow[t]{2}{*}{$\mathrm{OR}^{1}$} & \multicolumn{2}{|l|}{$95 \% \mathrm{CI}^{2}$} & \multirow[t]{2}{*}{$P$} & \multirow{2}{*}{$\mathrm{OR}^{1}$} & \multicolumn{2}{|l|}{$95 \% \mathrm{CI}^{2}$} & \multirow[t]{2}{*}{$P$} \\
\hline & & Lower & Upper & & & Lower & Upper & & & Lower & Upper & \\
\hline \multicolumn{13}{|l|}{$\begin{array}{l}\text { Residence } \\
\text { type }\end{array}$} \\
\hline Urban & 1.00 & & & & - & & & & - & & & \\
\hline Rural & 0.94 & 0.82 & 1.06 & 0.421 & - & - & - & - & - & - & - & - \\
\hline \multicolumn{13}{|l|}{ Geographical } \\
\hline \multicolumn{13}{|l|}{ Region } \\
\hline Central & 1.00 & & & & 1.00 & & & & 1.00 & & & \\
\hline West & 1.33 & 1.11 & 1.59 & 0.002 & 1.08 & 0.83 & 1.41 & 0.558 & 1.51 & 1.17 & 1.95 & 0.001 \\
\hline East & 1.40 & 1.19 & 1.65 & $<0.001$ & 1.54 & 1.23 & 1.94 & $<0.001$ & 1.27 & 1.00 & 1.62 & 0.048 \\
\hline \multicolumn{13}{|l|}{ Demographic } \\
\hline \multicolumn{13}{|l|}{ Gender } \\
\hline Male & 1.00 & & & & 1.00 & & & & 1.00 & & & \\
\hline Female & 1.35 & 1.17 & 1.55 & $<0.001$ & 1.46 & 1.19 & 1.79 & $<0.001$ & 1.23 & 1.01 & 1.51 & 0.042 \\
\hline \multicolumn{13}{|l|}{ Age (years) } \\
\hline$\leq 30$ & 1.00 & & & & 1.00 & & & & 1.00 & & & \\
\hline $31-40$ & 1.04 & 0.85 & 1.27 & 0.713 & 0.84 & 0.62 & 1.14 & 0.268 & 1.27 & 0.96 & 1.69 & 0.094 \\
\hline $41-50$ & 1.28 & 0.98 & 1.69 & 0.072 & 1.00 & 0.68 & 1.48 & 0.985 & 1.60 & 1.08 & 2.38 & 0.020 \\
\hline $51-60$ & 0.84 & 0.61 & 1.16 & 0.292 & 0.62 & 0.36 & 1.07 & 0.086 & 1.01 & 0.67 & 1.51 & 0.979 \\
\hline$\geq 61$ & 1.53 & 0.98 & 2.39 & 0.063 & 1.04 & 0.54 & 2.02 & 0.900 & 2.04 & 1.11 & 3.76 & 0.022 \\
\hline \multicolumn{13}{|l|}{ Marital status } \\
\hline Others & 1.00 & & & & 1.00 & & & & 1.00 & & & \\
\hline Married & 0.87 & 0.71 & 1.05 & 0.140 & 1.03 & 0.78 & 1.36 & 0.847 & 0.74 & 0.56 & 0.97 & 0.028 \\
\hline \multicolumn{13}{|l|}{ Education } \\
\hline $\begin{array}{l}\leq \text { Primary } \\
\text { school }\end{array}$ & 1.00 & & & & 1.00 & & & & 1.00 & & & \\
\hline $\begin{array}{l}\text { Middle-High } \\
\text { school }\end{array}$ & 0.96 & 0.66 & 1.39 & 0.829 & 1.28 & 0.67 & 2.45 & 0.456 & 0.84 & 0.53 & 1.33 & 0.445 \\
\hline$\geq$ University & 1.09 & 0.75 & 1.59 & 0.656 & 1.50 & 0.79 & 2.85 & 0.221 & 0.98 & 0.60 & 1.59 & 0.925 \\
\hline \multicolumn{13}{|l|}{ Employment } \\
\hline No & 1.00 & & & & 1.00 & & & & 1.00 & & & \\
\hline Yes & 0.87 & 0.73 & 1.04 & 0.134 & 1.11 & 0.85 & 1.46 & 0.444 & 0.71 & 0.56 & 0.90 & 0.005 \\
\hline \multicolumn{13}{|l|}{$\begin{array}{l}\text { Monthly income } \\
\text { (Chinese yuan) }\end{array}$} \\
\hline$<3300$ & 1.00 & & & & 1.00 & & & & 1.00 & & & \\
\hline 3300-5999 & 0.95 & 0.78 & 1.15 & 0.580 & 0.78 & 0.59 & 1.05 & 0.097 & 1.10 & 0.85 & 1.42 & 0.458 \\
\hline 6000-9999 & 0.98 & 0.77 & 1.25 & 0.892 & 0.71 & 0.50 & 1.01 & 0.058 & 1.27 & 0.91 & 1.78 & 0.165 \\
\hline$>10000$ & 1.04 & 0.78 & 1.40 & 0.787 & 0.78 & 0.51 & 1.20 & 0.260 & 1.29 & 0.83 & 1.99 & 0.256 \\
\hline Personal experie & nce & & & & & & & & & & & \\
\hline $\begin{array}{l}\text { Do you or any re } \\
\text { donation? }\end{array}$ & atives c & friend & ave an & xperien & organ & & & & & & & \\
\hline No & 1.00 & & & & 1.00 & & & & 1.00 & & & \\
\hline
\end{tabular}




\begin{tabular}{|c|c|c|c|c|c|c|c|c|c|c|c|c|}
\hline Yes & 1.58 & 1.13 & 2.21 & 0.008 & 1.42 & 0.90 & 2.22 & 0.128 & 1.90 & 1.13 & 3.21 & 0.016 \\
\hline \multicolumn{13}{|c|}{ Have you taken care of organ transplant patients? } \\
\hline No & 1.00 & & & & 1.00 & & & & 1.00 & & & \\
\hline Yes & 1.45 & 1.01 & 2.07 & 0.043 & 1.73 & 1.05 & 2.83 & 0.030 & 1.24 & 0.73 & 2.10 & 0.424 \\
\hline \multicolumn{13}{|c|}{ Have you participated in any volunteer activities? } \\
\hline No & 1.00 & & & & 1.00 & & & & 1.00 & & & \\
\hline Yes & 1.67 & 1.45 & 1.94 & $<0.001$ & 1.72 & 1.39 & 2.11 & $<0.001$ & 1.61 & 1.30 & 1.99 & $<0.001$ \\
\hline
\end{tabular}

${ }^{1}$ OR: Odds Ratio; ${ }^{2} \mathrm{CI}$ : Confidence Interval.

The results for subgroup analysis by rural-urban residence are also presented in Table 4. There were no significant interaction effects ( $P>0.05)$ between residence and any of the characteristics listed in Table 4, suggesting that the determinants of willingness to donate organ are similar for both urban and rural residents.

\section{Discussion}

\section{Main findings}

Empirical study plays an essential role in providing key information for experts and policymakers to take targeted measures to improve the number of organ donation registrations. In this study, we found that $47.45 \%$ ( $95 \% \mathrm{Cl}: 0.46$ to 0.49$)$ of the general public from three regions of China are willing to donate organs, which is similar to the percentage of organ donors in Germany $(46.8 \%)>10$ years ago ${ }^{22}$. Unsurprisingly, it is slightly higher than the percentage of organ donation for brain-dead patients $(41.8 \%)^{23}$. Our study shows that the proportion of the general population willing to donate organs in the three regions of China studied was lower than that previously reported in Chinese health professionals (49.3\%) ${ }^{17}, \mathrm{Chinese}$ transplantation patients and their caregivers $(62.7 \%){ }^{14}$, medical students in Spain (79\%) and in Germany $(63.5 \%){ }^{24-25}$. All things considered, willingness to donate organs in Eastern, Western and Central China is lower than in other countries of the world and suggests targeted measures should be implemented by the decision-makers and scientists to improve the situation.

A better understanding of the determinants of public willingness to donate organs will help to develop strategies to increase the rate of organ donation and meet the need of organ transplantation. The general public perceptions regarding willingness to organ donation are often underpinned by multiple sociodemographic factors, such as ethnicity, culture, religion and education ${ }^{26}$. Based on the findings of this study and supported by other studies ${ }^{27}$, urban-rural residence does not influence willingness to donate organs, Nevertheless, geographical region, gender, employment and personal experiences were shown to be the main determinants of willingness in the general public. In comparison to Central and Western China, individuals who lived in the urban area of Eastern China were more willing to donate organs. This could be explained by the social and economic developmental status of Eastern China, which is known to be a well-developed area in terms of economy and education, and the general public in this region would have a positive awareness of organ donation ${ }^{15}$.

Gender is directly associated with willingness to donate organs. In this study females had a higher propensity to donate their organs. This is similar to the findings of other studies ${ }^{21-22,27-28}$. Furthermore, an individual who, or whose relatives or friends had experienced organ donation, or individuals who had taken care of organ transplant patients or had undertaken voluntary related activities were more likely to donate organs. One potential reason is that they would have a better understanding of the importance of organ donation. Another reason relates to personal values. Participants who have altruistic values would be more willing to donate organs ${ }^{14}$.

\section{Limitations}

This study had several limitations. Firstly, this was an observational study in which the determinants of willingness to organ donation included were constrained by the pre-specified variables in the survey questionnaires. As a result, some potential unobserved confounding factors such as policy variables that are likely to have an impact on willingness to organ donation were not considered in the analysis. Presumed consent law and allocation priority were found to be effective measures to increase organ donation, for instance ${ }^{29-31}$. As a result, the observed differences in willingness to organ donation could be subject to possible unobserved confounding factors. Second, we were unable to collect detailed information on people's perceptions about organ donation. Finally, the study may suffer from potential selection bias. The study was only conducted in three regions (West, East, and Central) of China; there was direct contact between the investigators and the respondents during survey; the education level of the participants was higher than the general population in China according to the sixth census; the participants tended to be younger than the general population. These sampling issues suggest that our study sample may not be representative of the general population in China.

\section{Conclusions}


This study has attempted to evaluate the willingness of the general public to donate organs and to assess the influence of social-demographic characteristics and personal experience of determining the willingness of individuals to donate their organs. Overall, approximately half of the respondents were willing to donate organs and was higher in participants in Eastern and West China than in Central China. In addition, gender and personal experiences were independent determinants of an individual's willingness to organ donation. Our results provide valuable information for health experts and policymakers to promote organ donation in China.

\section{List Of Abbreviations}

\begin{tabular}{ll} 
Pmp & Per million population \\
\hline ORs & Odds ratios \\
\hline Cls & Confidence Intervals
\end{tabular}

\section{Declarations}

Ethics approval and consent to participate

Informed written consent was obtained from all study subjects before participating in the study. The study was conducted in accordance with the Declaration of Helsinki, and the protocol was approved by the Ethics Committee of Wenzhou Medical University (No.2019-054).

Consent for publication

Not applicable.

\section{Availability of data and materials}

The datasets generated for the current study are available from the corresponding author on reasonable request.

Competing interests

The authors declare that they have no competing interests.

Funding

This study was funded by the National Office for Philosophy and Social Sciences (No. 18BZX120). The funding body had no role in the design of the study and collection, analysis, and interpretation of data and in writing the manuscript.

\section{Authors' contributions}

Concept and designed the study: EL, DW, XF and ML. Collection of data: E., XF and ML. Analysis and interpretation of data: All authors. Wrote the manuscript: All Authors. Revision of the paper: EL, DW, ZZ and XF. All authors reviewed and approved the final manuscript.

\section{Acknowledgements}

We would like to express our appreciation to all participants in our study for their participation and cooperation, to the professors and students of Wenzhou Medical University, Xi'an Jiaotong University, Zhengzhou University and Hangzhou Normal University. We would also like to thank the village doctors and public health specialists from the village clinics, township hospitals and community health centres, who facilitated the surveys by inviting people on the streets, parks, shops and other public places, explaining the purpose of this survey, and spending time on the interviews.

\section{References}

1.Morris PJ. Transplantation - A medical miracle of the 20th century. New Engl J Med. 2004; 351 (26): 2678-2680.

2.Shimazono Y. The state of the international organ trade: a provisional picture based on integration of available information. Bull World Health Organ. 2007; 85 (12): 955-62.

3.Gomez MP, Perez B, Manyalich M. International Registry in Organ Donation and Transplantation-2013. Transplant Proc. 2014; 46 (4): $1044-8$.

4.Shacham E, Loux T, Barnidge EK, Lew D, Pappaterra L. Determinants of organ donation registration. Am J Transplant. $2018 ; 18$ (11): $2798-2803$.

5.IRODaT. http://www.irodat.org/?p=database\#data.

6.Moris D, Zavos G, Menoudakou G, Karampinis A, Boletis J. Organ donation during the financial crisis in Greece. Lancet. 2016; 387(10027):15111512

Page $12 / 14$ 
7.Goodarzi P, Aghayan HR, Larijani B, Rafiee AB, Falahzadeh K, Sahebjam M, Ghaderi F, Arjmand B. Tissue and organ donation and transplantation in Iran. Cell Tissue Bank. 2015; 16 (2): 295-301.

8.Fukushima N, Konaka S, Yasuhira M, Izawa M. Study of education program of in-hospital procurement transplant coordinators in Japan. Transplant Proc 2014, 46 (6), 2075-8.

9.Hu XP, Liu Y, Zhang XD. The organ donation in China. Chin Med J (Engl). 2012; 125 (21): 3912-3.

10.Abouna GM. Organ shortage crisis: problems and possible solutions. Transplant Proc. 2008; 40 (1): 34-8.

11.Shang X, Zhang M. Body and organ donation in Wuhan, China. Lancet. 2010; 376 (9746): 1033-4.

12.The Central People's Goverment of the People's Republic of China. Regulation on human organ transplantation. http://www.gov.cn/zwhd/200704/06/content_574340.htm.

13.Morgan SE, Harrison TR, Afifi WA, Long SD, Stephenson MT. In their own words: The reasons why people will (not) sign an organ donor card. Health Commun. 2008; 23 (1): 23-33.

14.Zhang QX, Xie JF, Zhou JD, Xiao SS, Liu AZ, Hu GQ, Chen Y, Wang CY. Impact Factors and Attitudes Toward Organ Donation Among Transplantation Patients and Their Caregivers in China. Transplant Proc. 2017; 49 (9): 1975-1981.

15.Zhang H, Zheng J, Liu W, Ding J, Zhang L, Zhang H, Zou Y, Fu Y. Investigation and Strategic Analysis of Public Willingness and Attitudes Toward Organ Donation in East China. Transplant Proc. 2015; 47 (8): 2419-24.

16.Lei L, Deng J, Zhang H, Dong H, Luo Y, Luo Y. Level of Organ Donation-Related Knowledge and Attitude and Willingness Toward Organ Donation Among a Group of University Students in Western China. Transpl P. 2018; 50 (10): 2924-2931.

17. Hu D, Huang H. Knowledge, Attitudes, and Willingness Toward Organ Donation Among Health Professionals in China. Transplantation. 2015; 99 (7): 1379-85.

18.Israni AK, Zaun D, Bolch C, Rosendale JD, Snyder JJ, Kasiske BL. Deceased Organ Donation. Am J Transplant. 2016; 16 Suppl 2: $195-215$.

19.Rumsey S, Hurford DP, Cole AK. Influence of knowledge and religiousness on attitudes toward organ donation. Transplant Proc. 2003; 35 (8): 284550 .

20.Ghaffari M, Rakhshanderou S, Najafizadeh K, Ramezankhani A, Latifi M. Determinants of medical students for intention to organ donation: Application of theory of planned behavior. Saudi J Kidney Dis Transpl. 2019; 30 (6): 1375-1380.

21.Mocan N, Tekin E. The determinants of the willingness to donate an organ among young adults: Evidence from the United States and the European Union. Soc Sci Med. 2007; 65 (12): 2527-2538.

22.Popp FC, Eggert N, Hoy L, Lang SA, Obed A, Piso P, Schlitt HJ, Dahlke MH. Who is willing to take the risk? Assessing the readiness for living liver donation in the general German population. J Med Ethics. 2006; 32 (7): 389-394.

23.Sandroni C, D'Arrigo S, Callaway CW, Cariou A, Dragancea I, Taccone FS, Antonelli M. The rate of brain death and organ donation in patients resuscitated from cardiac arrest: a systematic review and meta-analysis. Intensive Care Med. 2016; 42 (11): $1661-1671$.

24.Martinez-Alarcon L, Rios A, Gutierrez PR, Gomez FJ, Canadas-De la Fuente GA, Garcia-Mayor S, et al. Attitudes Toward Organ Donation: Differences Between Medical and Nursing Andalusian Students. Transplant Proc. 2020; S0041-1345 (19): 31226-6.

25.Inthorn J, Wohlke S, Schmidt F, Schicktanz S. Impact of gender and professional education on attitudes towards financial incentives for organ donation: results of a survey among 755 students of medicine and economics in Germany. BMC Med Ethics. 2014 ; 15 : 56.

26.Deedat S, Kenten C, Morgan M. What are effective approaches to increasing rates of organ donor registration among ethnic minority populations: a systematic review. Bmj Open. 2013; 3 (12): e003453.

27.Wilczek-Ruzyczka E, Milaniak I, Przybylowski P, Wierzbicki K, Sadowski J. Influence of empathy, beliefs, attitudes, and demographic variables on willingness to donate organs. Transplant Proc. 2014; 46 (8): 2505-8.

28.Stadlbauer V, Steiner P, Schweiger M, Sereinigg M, Tscheliessnigg KH, Freidl W, Stiegler P. Knowledge and attitude of ICU nurses, students and patients towards the Austrian organ donation law. BMC Med Ethics. 2013; 14: 32.

29.Zuniga-Fajuri A. Increasing organ donation by presumed consent and allocation priority: Chile. Bull World Health Organ. 2015 ; 93 (3): $199-202$. 
30.Rithalia A, McDaid C, Suekarran S, Myers L, Sowden A. Impact of presumed consent for organ donation on donation rates: a systematic review. BMJ. 2009; 338: a3162.

31.Li D, Hawley Z, Schnier K. Increasing organ donation via changes in the default choice or allocation rule. J Health Econ. 2013 ; 32 (6): 1117-29.

\section{Supplementary Files}

This is a list of supplementary files associated with this preprint. Click to download.

- Additionalfile1.pdf 